FRANCESCA PARMEGGIANI

Department of Modern Languages and Literatures Fordham University, New York
Images

vol. XXIV/no. 33

Poznań 2018

ISSN 1731-450x

\title{
Kieślowski Re-read: On Reality, Realism and Cinema
}

\begin{abstract}
Francesca Parmeggiani, Kieślowski Re-read: On Reality, Realism and Cinema. "Images” vol. XXIV, no. 33, Poznań 2018. Adam Mickiewicz University Press. Pp. 61-71. ISSN 1731-450X. DOI 10.14746/i.2018.33.06.

By referencing Italian auteurs Ermanno Olmi and Federico Fellini, this paper offers a re-reading of Krzysztof Kieślowskis reflections on cinema that places the practice of describing reality and uttering "a statement of fact" about people's lives and the world as a long-lasting, structuring foundation of his episteme and workshop.
\end{abstract}

KEYWORDS: description, Federico Fellini, Ermanno Olmi, reality, representation, statement of fact

"Il cinema non è un dopolavoro dove illudersi d'essere felici o constatare i propri fallimenti. Il cinema di ieri come quello di oggi vive il nostro medesimo sentimento della realtà".[1] With captivating and only apparent simplicity, Italian filmmaker Ermanno Olmi addresses a familiar question: what is cinema? His answer: cinema is not a marginal space and experience in our lives (merely a recreational club where we spend time after work); neither is it escapist illusion nor acknowledgment of our failings. Cinema - both filmmaking and film viewing, and their shared object - is a living creature that is bound by time as we are and that experiences the same "sentiment of reality" as we do. Cinema shares our ability to apprehend what surrounds us through the senses, feelings and the mind, and reflects our awareness of our corporeal and spiritual selves vis-à-vis and as part of reality. Like us and through us, cinema encounters reality, and, as Olmi describes it, "ferm[a] sulla pellicola uno sguardo originale che mostra della realtà ciò che altri non vedono" (it fixes on film an original gaze that shows a reality that others don't see).[2] In its relation to the visible and invisible world - reality - cinema is both (self-)knowledge, which stems from and returns to the domain of our senses, emotions and reason, and, as a technique, a means to achieve and share knowledge.

Olmi never met Krzysztof Kieślowski, but he called him "a friend." [3] That a "friendship", a perceived connection and reciprocal appreciation, existed between the two authors does not come as

[1] "Cinema is not a recreational club where you cultivate the illusion of being happy or admit to your failures. The cinema of today, like the cinema of the past, experiences the same sentiment of reality that we do" (E. Olmi, L'apocalisse è un lieto fine. Storie della mia vita e del nostro futuro, Milano 2012, p. 212, emphasis added). Unless otherwise noted, all translations from Italian into English are mine.

[2] E. Olmi, L'apocalisse è un lieto fine, p. 117.

[3] See: Krzysztof Kieślowski (1941-1996), ed.

S. Zawiśliński, Warsaw 2006, pp. 12-13 (a publication of the Polish Film Institute in Warsaw to 
a surprise. Although from different generations and different cultural backgrounds, despite the common influence of Catholicism, both directors made documentaries before turning to feature films, and treasured the technical knowledge and personal enrichment they gained from this experience.[4] They both acknowledge that this was a key experience in the definition of their aesthetic and the development of their poetics in later years.[5] More importantly, they share a humanistic approach to the world and its representation: their creative vision continuously shows genuine empathy for people and their daily struggles, and asserts the value of the person and of human knowledge when confronted with the mysteries of existence. While critics have questioned the simplicity and everyday-life naturalness of the stories and characters of Olmi's films as superficial and unable to tackle the complexity and conflicts in human existence, Kieślowski, instead, appreciated and possibly drew inspiration from them.[6] If Olmi's observations on what cinema is and how it works introduce us to the question of cinema's relentless engagement with reality and enduring realist ambition, Kieślowski's works and reflections offer us, in turn, a compelling case study to examine cinema's realist vocation and inclination.

Critics have extensively scrutinized and dissected Kieślowski's films and words with acumen and originality to highlight the novelty and complexity of his aesthetic - "an aesthetic of realist transparency" which "become[s] one of the reflexive" [7] - and the ethical commitment of his sustained investigations into the meaning and value of being human. His work has been discussed in the context of Polish modern history and film tradition and international cinema (primarily European and North American), and in relation to the changes in film production and visual culture occurring in Poland and the West since 1989.[8] My own contribution to revisiting Kieślowski aims at shedding

commemorate the director on the tenth anniversary of his death).

[4] However, unlike Kieślowski, who studied at the Łódź Film School, Olmi did not have any formal or academic training in filmmaking.

[5] Olmi speaks of his formation as follows: "io vengo dal mondo documentaristico e in particolar modo dal mondo del lavoro che ho documentato: quindi è un'influenza determinante" ["I come from the world of documentaries and, in particular, from the world of work, which I have documented: hence (this world) is a defining influence") (Ermanno Olmi. L'esperienza di Ipotesi Cinema, ed. E. Allegretti and G. Giraud, Genova 2001, pp. 188-189). He also explains that by observing the experience of people in the working environment to show the problems they confront and how these affect their personal lives, his early feature films (Il tempo si è fermato [1958], Il posto [1961] and I fidanzati [1963]) documented momentous socio- economic and cultural changes occurring in Italy in the 1950 and 1960s, which at the time were instead mostly disregarded (see: Ermanno Olmi, pp. 202-203). [6] See: M. Haltof, The Cinema of Krzysztof Kieślowski: Variations on Destiny and Chance, London and New York 2004, pp. 26-27 and 33.

[7] P. Coates, "Introduction", [in:] Lucid Dreams: The Films of Krzysztof Kieślowski, ed. Paul Coates, Trowbridge 1998, p. 11.

[8] In the vast and vibrant critical bibliography on Kieślowski in English, French and Italian, the following monographs and essay collections have more closely influenced or shaped my reading of his cinema: Kieślowski, ed. M. Furdal and R. Turigliatto, Torino 1989; Études Cinématographiques: Krzysztof Kieślowski (no. 203-210), ed. M. Estève, Paris 1994; Krzysztof Kieslowski, ed. V. Amiel, Paris 1997; V. Amiel, Kieślowski: la coscienza dello sguardo, Genova 1998; A. Insdorf, Double Lives, Second Chances: 
further light on the filmmaker's encounters with reality by exploring the cognitive cycle - from observation to description to knowledge - that structures his vision and approach to life, and informs its representation and expression, whether filming documentaries or directing feature films. It is tempting to read Kieślowski's poetics against Italian cinema's own negotiation with the complex terms of the relationship between reality and representation - what critics often discuss as the transition from neorealism to realism, from "the Italian School of the Liberation" (André Bazin) to auteur cinema - for this experience, which reverberated in much of postwar European filmmaking, has historically set the tone and offered examples for the critical study of cinematic realism from the mid-1940s through the 1960 s and beyond. In this paper, however, to show the integrity of Kieślowski's vision and artistry, I will only touch upon a few seemingly fleeting references that he made to Federico Fellini, whose films, La strada (1954) in particular, he greatly admired.

"I simply make movies and I tell stories, this has nothing to do with God. I am not creating the world... I am creating a drop of water in which the people who surround me are reflected".[9] With a beautiful image that reminds us of the visual and metaphorical play of the filmmaker with liquids, glasses and mirrors, streams and spills, and transparencies and reflections in his Decalogue (Dekalog, 1989) and later films, Kieślowski describes who he is and what he does: a filmmaker and a storyteller, he forges a tiny humble part of reality, "a drop of water," whose surface shows the images of the people around him. Sight cannot penetrate it, perhaps because the drop is too small or not clear, and yet the possibility persists - it is water, after all. The observer's perspective - the towering I of the (film)maker who is not God but comes through as godlike - is unusual, and challenges our attempt to describe and understand it: can it be at once from the centre and the sideline? And yet, it fascinates us and seems to make marvellous sense. The observer undoubtedly exists, as the creator states and the drop unequivocally demonstrates; he occupies a central position, both spatially and metaphorically, for people encircle him while he creates the tiny natural mirror that simultaneously reflects them. Yet, according to the inner logic of the image, he is not visible for the water does not reflect him. Perhaps out of sight, is the observer also reflected? Does he see, ignore, or overlook himself in the reflection? Do the people around him see him or are they wholly absorbed by their reflection in

The Cinema of Krzysztof Kieślowski, New York 1999; E. Wilson, Memory and Survival: The French Cinema of Krzysztof Kieślowski, Oxford 2000; S. Žižek, The Fright of Real Tears: Krzysztof Kieślowski between Theory and Post-Theory, London 2001; S. Murri, Krzysztof Kieślowski, Milano 2002; J.G. Kickasola, The Films of Krzysztof Kieslowski: The Liminal Image, New York 2004; After Kieślowski: The Legacy of Krzysztof Kieślowski, ed. S. Woodward, Detroit 2009; and
Lucid Dreams: The Films of Krzysztof Kieślowski, ed. P. Coates, and M. Haltof, The Cinema of Krzysztof Kieślowski, both referenced above.

[9] Cited in K. Monk, "Kieślowski: The End", [in:] Krzysztof Kieślowski: Interviews, ed. R. Bernard and S. Woodward, Jackson 2016, p. 145. Monk reports an interview with Kieślowski at the Vancouver International Film Festival in 1994. 
the water? Are we the people surrounding the filmmaker, reflected and reflecting ourselves in his creation, enchanted, the image of our being captured in it? With our gaze halted at the surface, we may recognize ourselves. Some of us don't go further; others long to see inside the drop or beyond its substance and our virtual existence; others turn their sight to the maker.

Kieślowski's carefully worded yet elusive self-portrait is also a short story in its own right, one of those stories (or dreams) that real life is made of, a script worth filming.[10] Accurately constructed to illustrate, beguile and mystify, it encapsulates the essence of his cinema. Cinema is creative labour that, through visual storytelling, expresses the director's investigation into human existence, and both controls and enables viewers' encounters with the world, their selves and other human beings. The filmmaker and storyteller is in fact like the puppeteer Bruce Schwartz (and, to some extent, his manipulative alter-ego Alexandre in The Double Life of Véronique [Podwójne życie Weroniki, 1991]), who, "within the space of a second," makes "a whole new world [appear]" without concealing his hands. His skilful performance triggers "beautiful reactions," and he rejoices at his work and the happy memories this evoked of the past.[11] He deeply cares for his characters, which come to life, and the life and emotions they bestow on him and his spectators in return. Like the drop of water in Kieślowski's description, cinema also mirrors reality, and in fact, people; it shows and gives back to them their images (who they are or have become). While it does not seek to impose an interpretation but only share a vision, it engages our senses and mind, prompting questions and "a conversation," whether we identify ourselves as the discursive subjects in the representation or are distant viewers contemplating from the outside.[12]

Let us consider these ideas a bit further. Cinema is material work, which Kieślowski carries out with rigor and precision. In many of his interviews, the director is adamant about the practical challenges that must be overcome when making movies, and the physical and emotional fatigue of realizing projects concurrently or in a short period of time,

[10] See: K. Kieślowski, “The Dramaturgy of the Real”, [in:] Krzysztof Kieślowski: Interviews, pp. 3-6 (particularly pp. 3-4), and K. Kieślowski, Kieślowski on Kieślowski, ed. D. Stok, London 1993, p. 63. [11] Moved by Schwartz's artistry and skill and the audience's responses to his mastery, Kieślowski explains: "after a second or two, you forget that the hands exist, because the doll lives its own life [...] you don't notice them; you only see the dancing" and continues on: "I saw a truly happy man. They're very gratifying, moments like these. The man was meant to come, animate his puppets and leave. But that's not the point. The point is that he came and suddenly rediscovered a past, a joy or happiness which he'd once had in the past and which he'd lost. He thought it would never come back, but with our film, it returned for a while. That's terribly important" (K. Kieślowski, Kieślowski on Kieślowski, pp. 180-182).

[12] In a 1990 interview with Tadeusz Sobolewski, Kieślowski explains: "When they ask me why I make [films], I always answer: because I want to have a conversation. How would you define searching for deep and non-existent film meanings if not as a kind of conversation? After all, a conversation is about finding in someone else what you don't have in you. And that in turn causes you to find in yourself something unexpected" (T. Sobolewski, "A Normal Moment", [in:] Krzysztof Kieślowski: Interviews, p. 75). 
subjected to political scrutiny and censorship or pressured by financial constraints and market demands. Cinema is also an intrinsic part of human experience precisely because it draws (or steals) its materials, its subjects and stories, from life itself, which it aims to describe in order to understand. In his writings and interviews, Kieślowski returns to the act of describing almost as often as he states the limits of his knowledge ("I don't know," he or his characters frequently utter or imply). He usually refers to the drive of his generation to describe the present world in order to characterize Polish cinema in the 1970 s and explain his and his colleagues' interest in documentary filmmaking. In the article "In Depth Rather than Breadth" (1981), for example, he writes:

As I saw it, the artist's fundamental obligation in the seventies was to describe. [...] If a particular aspect of reality is to be opposed and an alternative put forward, it must first be delineated. To fight evil [...] you must get its measure. You cannot dissent unless you have a clear idea of what you are dissenting from. [...] Skullduggery, raw deals, moral illiteracy, depravity can all occasion protest and revolt - but only after they have been called by the right name.[13]

Such political action to effect change is possible in a society only if the daily reality of its citizens is not simply shown, but is defined, gauged, experienced and understood through language. In 1991, looking back, once again, to his experience in the 1970s, Kieślowski comments further: "we found out that the world around us is a non-described world. [...] We also understood [...] that the world didn't have its own image. And we had the impression, I think accurate, that one could not understand the world unless it were described." [14] In Kieślowski's formulation, a description - the image resulting from describing the world, "how it actually looks" - is not a mere recording or transcription of what life is or how people live, only touching the surface of things. It has a specific function: it is a way of seeing and telling ("a statement of fact," he clarifies[15]) that allows filmmakers and viewers to establish an epistemological hold on reality, which is the necessary underpinning of any further reading and experience of the world. It is language that

[13] K. Kieślowski, "In Depth Rather than Breadth”, [in:] Krzysztof Kieślowski: Interviews, pp. 37-38, emphasis added.

[14] T. Szczepański, “Tree That Is”, [in:] Krzysztof Kieślowski: Interviews, p. 107. See: T. Lubelski, "From Personnel to No End: Kieślowski’s political feature films" (in Lucid Dreams, pp. 54-76) and M. Haltof, The Cinema of Krzysztof Kieślowski (particularly chapter two, "Film-Essays: Kieślowski and Polish Cinema in the 1970 and During the Solidarity Period," pp. 24-52) on the influence of Julian Kornhauser and Adam Zagajewski's generational manifesto, The Unrepresented World (Świat nieprzedstawiony, 1974) on Kieślowski's realism, which both critics discuss convincingly in relation to the socio-political and cultural context of Poland under Edward Gierek. [15] K. Kieślowski, Kieślowski on Kieślowski, p. 59. The expression "a statement of fact" also recalls Kieślowski’s essay on Ingmar Bergman's original description of unrepresented emotions in Silence (Tystnaden, 1963). Kieślowski states (and proceeds to illustrate): "Bergman's silence is a fact" (K. Kieślowski, "Bergman's Silence," trans. Paul Coates, [in:] Post-war Cinema and Modernity: A Film Reader, ed. J. Orr and O. Taxidou, New York 2001, p. 424). This utterance, conjuring the material evidence of truth, is the foundation of Kieślowski's reading of the film, which comprehensively also exemplifies his own poetics and method of work. 
informs knowledge and self-knowledge ("Only when you describe something can you start speculating about it [...] you can deal with it",[16] Kieślowski argues), which in turn enables action.

Far from being the director's work ethos only early in his career - as a documentary filmmaker who embraced the apparent technical versatility and inward gaze of fiction film[17] - I argue that this principle constitutes the foundation of Kieślowski's modus operandi, which he consistently puts to a test in his cinema and adapts accordingly, irrespective of the type of films he makes, whether documentary or fiction or a hybrid of the two forms.[18] My reading echoes Joseph Kickasola's when he discusses how in turning from documentary to fiction, Kieślowski continues to use documentary techniques and combines them with more formalist ones to explore metaphysical themes. Kickasola reasons that in Kieślowski's later films,

representation creates the 'realist' context, the immanent boundaries of which are challenged by form, mediating the 'unrepresentable.' This mediation is a phenomenological incarnation of non-rational knowledge and is often seen as bleeding over into supernatural experience (or providing an index of such). Whether it actually does so is a matter of faith, and Kieślowski encourages us to examine where our faith lies.[19]

Kickasola's analysis, tinged with spiritual and transcendental undertones, is in line with French and anglophone scholarship on Kieślowski, which tends to view the evolution of his aesthetic as a turning away from realism as a hermeneutic tool, for the depth of human experience, its mysteries (including faith), can only be expressed, explored or directly experienced through non-rational means (namely the senses, feelings and emotions, or silence - Kickasola's leap of faith). Hence the filmmaker's choice of formal experimentation, artifice and abstraction, and, at the end of his career, retirement from filmmaking, caused by the distrust of cinema's ability not only to represent reality, but also to understand it, to distinguish between the virtual and the real.[20] My

[16] K. Kieślowski, Kieślowski on Kieślowski, p. 58.

[17] See the compelling analyses that Paul Coates and Lubelski offer of this experience in "Kieślowski and the crisis of documentary" and "From Personnel to No End" respectively (in Lucid Dreams, pp. 32-53 and 54-76).

[18] By Kieślowski's own admission, in his cinema, formulated ideas drive the narrative and guide the imagination. He states: "I think that what has stayed with me is that my feature films unfold more with the help of the idea rather than the help of the action. [...] I don't know how to narrate action" (Krzysztof Kieślowski, Kieślowski on Kieślowski, p. 102). Kieślowski thus bypasses the description/narration dichotomy at the center of much discussion on realism in literature and film at the time, favoring the hybridization of practice over the purity of theory.
[19] J.G. Kickasola, The Films of Krzysztof Kieslowski, pp. 25-26.

[20] See: V. Amiel, Kieślowski: la coscienza dello sguardo. We are also reminded of Kieślowski's words on his retirement from filmmaking: "I started to live in a fictional world that I imagined, and was artificial. I ceased participating in real life and started in the one that I invented either alone or with my colleague Piesiewicz. [...] I lost the feeling that I was communicating with the world. I drove myself into some fictitious world; I removed myself from those near and dear to me because fictitious problems started to become extremely important" (cited in M. Haltof, The Cinema of Krzysztof Kieślowski, pp. 149-150). 
analysis, however, proposes to read Kieślowski's realism, which in fact he never refuted but always tested and endlessly adapted, as a sustained, albeit exhausting epistemological and hermeneutical engagement with the visible and invisible of the human condition in the world.

While at some point many of his colleagues "began to chafe at the predominance of description" out of concern for the limitations documentary filmmaking imposed on their imagination, expression and artistic freedom, [21] describing and description continued to be critical terms in Kieślowski's idiolect and practice throughout his career. Even when Kieślowski declares: "Not everything can be described",[22] signalling a watershed moment in his aesthetic, when he turned from documentary to fiction on account of his "fright of real tears" (Slavoj Žižek) but also, as Kieślowski points out in several interviews, out of a legitimate concern that his work might be misused by the Polish government against the people he filmed, he is not in fact disavowing the function and scope of description, but rather he is reassessing its subjects. The (self-)knowledge and painful awareness of its limits (he writes, "the very feeling of not knowing is a painful one" [23]) that the practice of describing reality through images, words and sounds has made possible - a reality comprising "persons in social situations" [24] now prompt the filmmaker's inquisitive eye to delve deeper into the world and people's lives, and to look beyond the geopolitical and cultural boundaries of his native Poland. He continues to describe by filming, and build knowledge, striving to make sense of who we are, what we do and why we do it, with an ever richer and more sophisticated filmic language, where frames and sequences, sharply constructed, function as cognitive units or statements of facts, and which he adjusts not only to fit his new subjects but also to tighten the intellectual and affective connection with his viewers. [25]

Describing the world is not just photographing it; description "brings something to life". Kieślowski often returns to this particular effect of the act of describing when he explains his documentary work in the 1970s. In relation to Workers ' 71 (Robotnicy 1971: Nic o nas bez nas, 1971), for example, he observes:

[21] K. Kieślowski, "In Depth Rather than Breadth", p. 38.

[22] K. Kieślowski, Kieślowski on Kieślowski, p. 86.

[23] K. Kieślowski and K. Piesiewicz, Decalogue: The

Ten Commandments, trans. P. Cavendish and S. Bluh, London-Boston 1991, p. xiv.

[24] I adapt Kieślowski’s words to Tadeusz Szczepański: "I have never made films about a social being, I've made films about a person in a social situation" (T. Szczepański, "Tree That Is," p. 107).

[25] The Decalogue film cycle is perhaps the work that presents most clearly the tension between the filmmaker's intensifying interest in universal, existential themes and increasing disinterest in local politics, which "don't solve the really important human questions” (K. Kieślowski, Kieślowski on Kieślowski, p. 144). However, in the films, neither perspective cancels the other out. On the tension between the universal and the particular, the personal and the historical see S. Žižek, The Fright of Real Tears, and Of Elephants and Toothaches: Ethics, Politics, and Religion in Krzysztof Kieślowski's 'Decalogue', ed. E. Badowska and F. Parmeggiani, New York 2016, particularly E. Badowska, "States of Exception: Politics and Poetics in Decalogue Six" (pp. 140-164). 
The Communist world had described how it should be and not how it really was. We - there were a lot of us - tried to describe this world and it was fascinating to describe something which hadn't been described yet. It's a feeling of bringing something to life, because it is a bit like that. If something hasn't been described, then it doesn't officially exist. So that if we start describing it, we bring it to life.[26]

The circumstances and experiences of people's everyday lives become recognized and recognizable and are the object of collective fruition through film. The notion of an "official existence," countering the official history of authoritarian regimes, and the liberating experience of "speaking in public" persist as an underlying vocation and concern in Kieślowski's cinema.[27] In reflecting on The Double Life of Véronique, specifically on the doomed relationship between Véronique and Alexandre because she realizes that Alexandre has appropriated her photos "perhaps [understanding] what she couldn't understand herself," Kieślowski comments on this new, unearthed life of Véronique - in fact, an exposure of her self that she did not expect - as follows:

the moment this came out into the open, something she possessed, something which was so terribly intimate as long as it wasn't disclosed, was automatically, or almost automatically, used. And when it was used, it stopped being hers: and when it stopped being hers, it was no longer mysterious. It was no longer personal. It had become a public secret.[28]

This powerful oxymoron, "a public secret," reveals that Kieślowski is still wary of the implications of "bringing to life," and to public fruition, people's experiences - Véronique’s photographs disguise Kieślowski's films. In Communist Poland, this practice intruded into and exposed the personal life of his fellow citizens and potentially endangered their public existence. In the "regime of freedom" of Western democracy - or perhaps it is just a sign of the long-lasting and unshakably pernicious invasiveness of Communism[29] - it is still an intrusion into people's lives and their exposure to the uses and misuses by others. Furthermore, the director also underscores that the violation of this privacy - the loss of one's mystery - equals a loss of self-possession; it disenfranchises the individual. As a consequence, however, the individual, off-balance but more self-aware, is compelled to action, and makes momentous decisions (Véronique goes back to her father and origins). Describing the inquiry that the director relentlessly pursues and painstakingly

[26] K. Kieślowski, Kieślowski on Kieślowski, pp. 54-55. [27] Speaking of contemporary Polish cinema, Kieślowski explains to Ginette Gervais in 1979: “There is much debate, even in the press, because everyone has realized that film touches on problems about which no one has spoken in public. But I stress the imperfection; it's a start; we have not seen a La strada yet, but it will come!" (G. Gervais, "Interview with Krzysztof Kieślowski”, [in:] Krzysztof Kieślowski:
Interviews, p. 26). I will return to Kieślowski's interest in and recurring mention of Federico Fellini’s 1954 masterpiece, La strada.

[28] K. Kieślowski, Kieślowski on Kieślowski, p. 187, emphasis added.

[29] "[Communism] infiltrated everything", says Kieślowski (T. Sobolewski, “A Normal Moment”, [in:] Krzysztof Kieślowski: Interviews, p. 79). 
formulates - produces knowledge, a "statement of fact," in the form of an irreversible, yet productive trespassing against and within the self.

In the often cited passage in which Kieślowski admits to his fright of real emotions and justifies his "escape from documentaries" (rather than flight to fiction), critics generally overlook the subtle motif of the irreversibility of individual actions or conditions and their ensuing emotions.[30] Kieślowski wonders whether "[he has] got the right to photograph them," testing the ethical boundaries of filmic representation. At the same time, his praise for the ease of using glycerin to fake tears - and elsewhere, of working with professional actors, for "real people [...] cannot take the mask off"[31] - points to the definitiveness of experience, whereby gains and losses are set once and for all. The definitiveness that human experiences hold by virtue of their emotional depth and intensity both appeals to and frightens the author because it confronts him with the ambivalence and responsibility of freedom, which he cannot conveniently dismiss or ignore, or, pace Žižek, simplistically take distance from through fiction. Kieślowski states further: "I feel like somebody who's found himself in a realm which is, in fact, out of bounds," where the expression "out of bounds" conjures the idea on the one hand, of the filmmaker's observation as trespassing boundaries and, on the other hand, of his novel work within a boundless territory.[32]

In Kieślowski's reflection on his experience as a filmmaker, the process of describing, whose end result is existence-brought-to-life and added understanding of reality, achieves another objective. In commenting on the interpretive frenzy that his films appear to trigger in the audience, the author explains to Tadeusz Sobolewski: "It fascinates me that people notice and interpret some things that are unnamed or even unexpressed in the film. This is how they come to life".[33] Elsewhere, speaking of his collaboration with Zbigniew Preisner on The Double Life of Véronique and the ways music works in a film, he says:

You show the composer your film and then he fills the gaps with music. But
he can have a different approach. He can think about the music right from
the start, about its dramatic function, about the way it should say something
that's not there in the picture. You can describe something which perhaps
isn't there on the actual screen but which, together with the music, starts
to exist. It's interesting - drawing out something which doesn't exist in the
picture alone or in the music alone. Combining the two, a certain meaning,
a certain value, something which also determines a certain atmosphere,
suddenly begins to exist.[34]

The two excerpts illustrate the same phenomenon from two different, yet complementary perspectives, that of the viewer, who interprets, and that of the artist(s), who create(s). A film "comes to life" - its meanings

[30] K. Kieślowski, Kieślowski on Kieślowski, p. 86. [31] T. Sobolewski, "Behind the Curtain", [in:] Krzysztof Kieślowski: Interviews, p. 127.
[32] K. Kieślowski, Kieślowski on Kieślowski, p. 86.

[33] T. Sobolewski, "A Normal Moment", p. 75.

[34] K. Kieślowski, Kieślowski on Kieślowski, p. 179. 
and atmospheres "start to exist" - when it challenges the literalness of the image, of the language through which it speaks. The filmmaker acknowledges the difficulty of striking a balance between how much he can or cannot show, between the self-evidence of his "statement of fact", namely his film, and the complexity of the process that led to its utterance: "If I show too much the mystery [what is not immediately perceivable by the eye] disappears; I can't show too little because nobody will understand anything" (or else, will get lost in endless interpretations). He continues on self-deprecatingly: "[cinema is] not intelligent enough" because it is "too explicit" and "too equivocal". [35] And yet, he strives to capture reality because his ultimate goal is "to stir people to something" by creating "a description, an image which deeply concerns you, which deeply moves you and is your image. [...] That's what great film-making's about [...] For a brief moment, you find yourself there".[36]

We are taken back to the drop of water of our beginning, reflecting the people around the filmmaker, most likely himself too, although he steps aside, discreetly yet controllingly. No emotion, passion or feeling is represented in Kieślowski's description of himself and his cinema, but we are not dissuaded by the literalness of the image or the factuality of his statement. "Things are very rarely said straight out in my films", Kieślowski acknowledges - an observation that also applies in this instance. Kieślowski's silence is rich with meaning; it exudes the tension inherent in his relationship with reality and its representation, but also evokes "the magic of the screen" that he strives for:

That suddenly, as an audience, you find yourself in a state of tension because you're in a world shown to you by the director. That world is so coherent, so comprehensive, so succinct that you're transported into it and experience tension because you sense the tension between the characters.[37]

Significantly, these words describe Kieślowski's viewing experience of Fellini's La strada, "a good film" - Simon Hattenstone reports Kieślowski saying - because, like all good movies should do, it "manages to describe the world as it is while also creating its own world". [38] Cinema neither cultivates our illusions nor harbors our failures, but rather encompasses the world that we learn to know through our sensual, emotional and rational experiences and through our imagination.

Allegretti E. and Giraud G. (eds.), Ermanno Olmi. L'esperienza di Ipotesi Cinema, Genova 2001

Amiel V. (ed.), Krzysztof Kieslowski, Paris 1997

Amiel V., Kieślowski: la coscienza dello sguardo, Genova 1998

[35] K. Kieślowski, Kieślowski on Kieślowski, pp. 173 and 195 .

[36] Ibidem, p. 193

[37] Ibidem, p. 33.
[38] S. Hattenstone, "Auteur of His Own Destruction", [in:] Krzysztof Kieślowski: Interviews, p. 149. 
Badowska E. and Parmeggiani F. (eds.), Of Elephants and Toothaches: Ethics, Politics, and Religion in Krzysztof Kieślowski's 'Decalogue', New York 2016

Bernard R. and Woodward S. (eds.), Krzysztof Kieślowski: Interviews, Jackson 2016

Coates P. (ed.), Lucid Dreams: The Films of Krzysztof Kieślowski, Trowbridge 1998

Estève M. (ed.), Études Cinématographiques: Krzysztof Kieślowski (no. 203-210), Paris 1994

Furdal M. and Turigliatto R. (eds.), Kieślowski, Torino 1989

Haltof M., The Cinema of Krzysztof Kieślowski: Variations on Destiny and Chance, London-New York 2004

Insdorf A., Double Lives, Second Chances: The Cinema of Krzysztof Kieślowski, New York 1999

Kickasola J.G., The Films of Krzysztof Kieslowski: The Liminal Image, New York 2004

Kieślowski K. and Piesiewicz K., Decalogue: The Ten Commandments, trans. P. Cavendish and S. Bluh, London-Boston 1991

Kieślowski K., Kieślowski on Kieślowski, ed. D. Stok, London 1993

Kieślowski K., "Bergman's Silence," trans. Paul Coates, [in:] Post-war Cinema and Modernity: A Film Reader, ed. J. Orr and O. Taxidou, New York 2001, pp. $422-425$

Murri S., Krzysztof Kieślowski, Milano 2002

Olmi E., L'apocalisse è un lieto fine. Storie della mia vita e del nostro futuro, Milano 2012

Wilson E., Memory and Survival: The French Cinema of Krzysztof Kieślowski, Oxford 2000

Woodward S. (ed.), After Kieślowski: The Legacy of Krzysztof Kieślowski, Detroit 2009

Zawiśliński S. (ed.), Krzysztof Kieślowski (1941-1996), Warsaw 2006

Žižek S., The Fright of Real Tears: Krzysztof Kieślowski between Theory and Post-Theory, London 2001 